\title{
ASSESSMENT OF PV INTEGRATION IN THE INDUSTRIAL AND RESIDENTIAL SECTOR UNDER ENERGY MARKET CONDITIONS
}

\author{
L. Petrichenko ${ }^{1 *}$, J. Kozadajevs ${ }^{1}$, R. Petrichenko ${ }^{1}$, \\ O. Ozgonenel ${ }^{2}$, D. Boreiko ${ }^{1}$, A. Dolgicers ${ }^{1}$ \\ ${ }^{1}$ Riga Technical University, Institute of Power Engineering, \\ 12-1 Azenes Street, Riga, LV-1010, LATVIA \\ 2 Department of Electrical-Electronics Engineering, \\ Ondokuz Mayis University, Samsun, TURKEY \\ *e-mail: lubova.petricenko@rtu.Iv
}

The paper assesses the integration of solar photovoltaic technology in the industrial and residential sectors under energy market conditions. The aim is to determine and compare the payback period for the use of solar photovoltaic technology between the industrial and residential sectors, taking into account the application of optimal load scheduling and level of direct consumption. The industrial sector is represented by a glassware company. Installing PV technologies for a larger area and power is cheaper than installing low-power solar photovoltaic technologies. In addition, direct consumption has significant benefit due to high network service tariffs.

Keywords: Industrial consumer, load scheduling, payback period, prosumer, PV technology, optimisation.

\section{INTRODUCTION}

Renewable energy sources (RESs), such as wind and solar energy, have the potential to reduce dependence on fossil fuels. The share of RESs employed in meeting the global energy demand is expected to grow by one fifth in the next five years and to reach $12.4 \%$ in 2023 . In the near future,
RESs are forecast to meet more than $70 \%$ of the growth in global electricity generation, led by solar photovoltaic technology (PV) and followed by wind, hydropower and bioenergy [1].

The electricity sector continues to have greatest opportunity for RESs, with 
an exponential growth in the use of solar PV in recent years. More than $486 \mathrm{GW}$ of installed capacity makes solar energy the third largest RES in the world, with photovoltaic technology being dominant [2]. PV is in high demand in the global solar energy market for both residential and industrial buildings. In addition, the cost of PV has been reducing in recent years [3]. This has encouraged the introduction of feed-in tariff programmes in many countries. However, implementing a net metering policy poses a key challenge. Net metering is important for residential consumers [4] as PV creates a significant amount of surplus power during the middle of the day, when households typically consume less power [5].

A significant volume of research has investigated the opportunities and challenges associated with the wide-spread deployment of PV [6]. An analysis of several publications that have examined the use of PV technology in industry is presented in [7].

Unlike traditional fossil fuel plants and renewable electricity production forms (such as biomass, pumped hydropower and geothermal energy), wind and the sun only provide power when the RES is available. This makes them less predictable. The variability in electricity power generation must be accounted for in order to maximise the penetration of renewable energy into the power system, and ensure a match between electricity supply and demand at all times. To avoid imbalances that jeopardise system stability, action to introduce new energy storage and demand response (DR) technologies will be required.

DR provides an opportunity for consumers to play a significant role in the operation of the electric grid by reducing or shifting their electricity use during peak periods in response to time-based rates or other forms of financial incentives [8], [9]. The electric power industry considers DR programmes to be an increasingly valuable approach to resource management, with capabilities and potential effects being expanded by grid modernisation and smart metering efforts. DR decreases the need for local network investment, as it can shift consumption away from peak periods, with the greatest benefit in regions with a network capacity close to maximum.

To fulfil the energy goals of the European Union and its political promises, the full range of demand-side resources, available at competitive prices, must be engaged, and all consumers must have the ability to benefit from their flexibility [10].

The EU Energy Efficiency Directive encourages energy auditing and the implementation of energy efficiency measures at SMEs (small and medium-sized enterprises) [11]. In response, legislation in Latvia stipulates that enterprises with the high energy consumption have to comply with the energy efficiency standard LVS EN ISO 50001:2012 [12]. However the standard LVS EN ISO 50001:2012 currently lacks coordination between energy efficiency and DR and only refers to using less primary energy.

Much work has been done in recent years to implement industrial demand-side management at energy-intensive enterprises. The focus has been to develop models and optimisation algorithms to provide effective solutions for real-life production scheduling. Scheduling has been receiving considerable attention from the Process Systems Engineering Community, particularly for batch plants. The review paper by Méndez et al. (2006) provides a classification and a conceptual overview of the most important approaches. Research in the past 15 years has focused on continuous-time formulations [13]-[16].

However, the literature on PV and algorithms for optimal load scheduling has 
not fully considered coordination of load scheduling with PV technology.

The present study compares the payback period (PP) of the use of PV technology between the industrial and residential sector, taking into account the application of optimal load scheduling for industry. The study:

- determines the amount of electricity that can be produced by PV considering typical solar irradiation and the capacity of the PV;

- considers optimisation of load scheduling;

- determines the cost, revenue and savings considering market conditions;

- considers the electricity price policy and optimal load scheduling for the case study of a factory to determine the PP of the PV technology.

The main contributions of the paper are as follows:

- comparison of the PP of PV technologies for an enterprise and for a household;

- analysis of the effectiveness of the proposed approach.

The rest of the article is organised as follows: Section 2 is devoted to the description of the methodology, models, constraints and the rules of the current billing system. Section 3 contains a description of the initial data and assumptions, as well as reflects the calculation results of the NPV of PV technologies. The last section is devoted to conclusions.

\section{METHODOLOGY AND MODELS}

\section{A. PV Generation}

Geographical and weather conditions are inherently important for PV systems. As an example, Latvia has similar potential to use solar energy as Germany and England, where PV technologies have been widely used [17].

The evaluation of PV generation can be performed by using two approaches:

1. A theoretical (statistical) approach, where PV generation is modelled using constant and time-varying parameters. One of the simplified methods for the calculation of hourly PV-generated electricity $\left(W_{\text {gen.PV }, t}\right)$ is as in $(1)$ :

$W_{g e n . P V, t}=\operatorname{Rad}_{t} \cdot \eta_{P V} \cdot S_{P V}=\operatorname{Rad}_{t} \cdot \eta_{P V} \cdot 6.4 \cdot W_{P V}$,

where

$t$ - time step, usually one hour; $S_{P V}$ - the rated area of installed PV technology, $\mathrm{m}^{2} ; \mathrm{\eta}_{P V}-$ efficiency of the PV; 6.4 - an area corresponding to $1 \mathrm{~kW}$ of installed capacity, $\mathrm{m}^{2} / \mathrm{kW}[18]$; $W_{P V}-\mathrm{PV}$ capacity, $\mathrm{kW} ; \operatorname{Rad}_{t}-$ hourly solar irradiation, $\mathrm{kWh} / \mathrm{m}^{2}$.

Solar irradiation is determined by considering Latvian hourly irradiation data received from the meteorological service [19].

2. An experimental approach, where the generation of the $\mathrm{PV}$ is determined from locally measured data.

Figure 1 shows a comparison of the two approaches for a specific plant, which is located in the city of Jelgava. The maximum power for the $\mathrm{PV}$ is $5.88 \mathrm{~kW}$. 


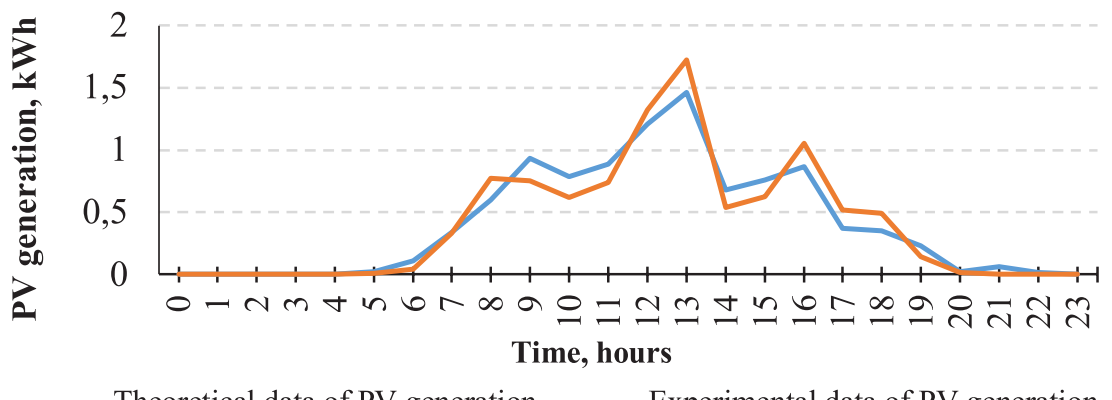

Theoretical data of PV generation —_Experimental data of PV generation

Fig. 1. Fragment of hourly PV generation data of the plant in Jelgava (24/06/2018).

In Fig. 1, we observe that the PV generation by the theoretical approach is similar to the experimental data, with an error of $20 \%$ on average. This difference is due to local weather phenomena (cloud cover) or influence of specific sight (trees, buildings, etc.). Many factors affect the accurate determination of PV generation [21]; however, we consider statistical data to be sufficiently accurate for this work, and data are taken from the open access database, SolarEdge (country: Latvia) [20].

\section{B. Electricity Billing System and Avoided Cost}

We use the Latvian model of electricity billing for electricity tariffs. This consists of five components: the energy price $(p)$; a capacity-based connection fee paid to the distribution system operator $\left(p_{\text {con.distr }}\right)$; an energy-based electricity distribution fee $\left(p_{\text {en distr }}\right)$; the mandatory procurement component for the connection $\left(p_{\text {con.mpc }}\right)$; and for the electricity consumed from the grid $\left(p_{\text {en } m p c}\right)$.

To determine the economic efficiency of PV, we calculate the avoided cost (AC) for the factory, where $\mathrm{AC}\left(C_{A C_{-} \text {total,y }}(€)\right)$ is defined as the sum of two terms: the difference between the cost of energy in the case when no PV technology is installed $\left(\left(C_{\text {base } y}\right)(€)\right)$ and the cost of energy when using PV technology $\left.\left(C_{P V}, y\right)(€)\right)$; and the difference between the cost of energy in the case when no load scheduling is applied $\left(\left(C_{\text {base } y}\right)(€)\right)$ and the cost of energy when load scheduling is applied $\left.\left(C_{L S, y}\right)(€)\right)$. Thus, the total AC for a year, $y$, is as (2):

$C_{A C_{-} \text {total,y }}=C_{A C_{P V}, y}+C_{A C_{L S}, y}=\left(C_{\text {base }, y}-C_{P V, y}\right)+\left(C_{b a s e, y}-C_{L S, y}\right)$

where

$y$ - the discretisation step in the planning period of the cash flow, usually one year; $C_{A C_{P V} y}-$ cost avoided that is considered as the difference between the cost of the electricity consumed when PV technology is not installed and optimal load scheduling is not used $\left(C_{\text {base,y }}\right)$, and the cost when it is installed $\left(C_{P V} y\right)$ and load scheduling is used, in year $y, € ; C_{A C_{L S}} y-\operatorname{cost}$ avoided that is considered as the difference between the cost of electricity consumed when PV technology is not installed and optimal load scheduling is not used $\left(C_{\text {base,y }}\right)$, and when only load scheduling is applied $\left(C_{L S, y}\right)$, in year $y, €$. 
The annual cost $\left(C_{y}\right)$ for the energy consumption of the factory before PV installa- tion and before the use of load scheduling is estimated as (3):

$$
\begin{aligned}
C_{y}=C_{\text {base }, y} & \\
& =p_{\text {con.distr }}+p_{\text {con.mpc }} \\
& +\sum_{d=1}^{365} \sum_{t=1}^{24} \sum_{n=1}^{N} W_{\text {cons }, n}^{t, d} \cdot\left(p^{t, d}+p_{\text {en.distr }}^{t, d}+p_{\text {en.mpc }}^{t, d}\right)
\end{aligned}
$$

where

$C_{\text {base,y }}$ - the cost of energy consumption before PV installation and before the use of load scheduling in year $y$ (the base case), $€ ; N$ - the number of production processes; $W_{\text {cons,n }}^{t, d}-$ the energy consumption of the $n$-th manufacturing process in the factory at hour $t$ on day $d$, kWh.

The annual cost for the factory after the use of load scheduling $\left(C_{L S, y}\right)$ is as (4): installing PV technology $\left(C_{P V}, y\right)$ and after

$$
\begin{aligned}
C_{P V, y}=p_{\text {con.distr }}+p_{\text {con.mpc }} & \\
& +\left(\sum _ { d = 1 } ^ { 3 6 5 } \sum _ { t = 1 } ^ { 2 4 } \left(\sum_{n=1}^{N}\left(W_{\text {cons }, n}^{t, d} \cdot\left(p^{t, d}+p_{\text {en.distr }}^{t, d}+p_{\text {en.mpc }}^{t, d}\right)\right)-W_{\text {gen.PV }}^{t, d}\right.\right. \\
& \left.\cdot\left(p^{t, d}+p_{\text {en.distr }}^{t, d}+p_{\text {en.mpc }}^{t, d}\right)\right),
\end{aligned}
$$

$$
\begin{aligned}
& C_{L S, y}=p_{\text {con.distr }}+p_{\text {con.mpc }} \\
& +\sum_{d=1}^{365} \sum_{t=1}^{24} \sum_{n=1}^{N} W_{\text {consLS,n }}^{t, d} \cdot\left(p^{t, d}+p_{\text {en.distr }}^{t, d}+p_{\text {en.mpc }}^{t, d}\right)
\end{aligned}
$$

where $W_{\text {consLS, } n}^{t, d}$ - the energy consumption of the $n$-th manufacturing process in the factory after load scheduling at hour $t$ on day $t, \mathrm{kWh}$.

\section{Methodology of Feasibility Studies}

We investigate and compare the $\mathrm{AC}$ that results from the use of PV and load planning. Economic criterion, such as the net present value of the cash flow (NPV), is usually used for analysis; however, the discounted PP $\left(T_{P P}\right)$ is also included in this work as it provides a meaningful economic criterion for comparison of PV integration in the industrial and residential sectors. $T_{P P}$ determines the time at which the cumulative savings will exceed the investment cost of the PV technology. It is necessary to notice that, in contrast to the simple PP, the discounted PP takes into account the time 
value of money [22]. The NPV has been presented in our previous papers [4], [23]. The PP formulation is given in [24], [25].
By using the NPV formulation, the optimisation task can be formulated in the following form:

$N P V\left(T_{\text {plan }}\right)=-p_{\text {inv }}+\sum_{y=1}^{T_{p l a n}} \frac{R_{y}}{\left(1+i_{d}\right)^{y}}, \rightarrow \max$

where

$T_{\text {plan }}$ - the planning period, years; $p_{i n v}-$ initial investment for the PV technology, $€ ; i_{d}-\mathrm{a}$ discount rate; $R_{y}-$ a net cash flow, i.e., the difference between inflow and outflow of cash in year $\mathrm{y}, \epsilon$.

Forecasts for the parameters are used in this paper. These have been determined from measurements of the parameters under consideration (PV generation $\left(W_{\text {gen.PV }, t}\right)$, electricity consumption ( $\left.W_{\text {cons }}\right)$, energy price $\left(p_{t}\right)$ ) by using a naïve forecasting approach based on the assumption that the values of the parameters remain constant.

\section{CASE STUDY}

\section{A. The Object under Consideration}

The optimisation model was applied to a glass processing company in Latvia, with an annual production of $16,500 \mathrm{~m}^{2}$ of glass. The glass factory produces several types of glass product.

The finished products, including tempered glass, insulating glass units, laminated glass and structural glazing, undergo six technological processes:

1. Cutting - obtaining semi-finished products for further processing by means of a cutting machine with a capacity of $288 \mathrm{~m}^{2} / \mathrm{h}$;

2. Finishing - providing the glass with a marketable condition and observing the process requirements for further manufacturing processes; for this purpose, three machines with a total capacity of $150 \mathrm{~m}^{2} / \mathrm{h}$ can be used;

3. Tempering - providing the glass with special physical properties. If necessary, using it in further manufacturing processes, equipment capacity $144 \mathrm{~m}^{2} / \mathrm{h}$. It should be noted that the energy consumption for glass tempering is continuous. The equipment consumes a significant amount of electricity even in standby mode;

4. Lamination - gluing two or more glass sheets together; a machine with a capacity of $1.33 \mathrm{~m}^{2} / \mathrm{h}$ is used;

5. Insulating - producing insulating glass units with a capacity of $50 \mathrm{~m}^{2} / \mathrm{h}$;

6. Painting - a capacity of $50 \mathrm{~m}^{2} / \mathrm{h}$.

The average time and electricity consumption to produce $1 \mathrm{~m}^{2}$ of finished glass product will depend on the type of finished product. Other factors that affect electricity consumption include the thickness, size, and shape of the glass, which are not considered in this analysis. 
The various products involve many different processes. The processes for the most common products are detailed here and shown in Fig. 2:

1. Structural glazing - cutting and finishing;

2. Insulating glass in single-chamber form (two sheets of glass): cutting, finishing and insulating;

3. Tempered glass - cutting, finishing and tempering;
4. Laminated glass - cutting, finishing, tempering and lamination;

5. For insulating glass in two-chamber form (three sheets of glass) - cutting, finishing, tempering and insulating;

6. Insulating glass in single-chamber form (two sheets of glass) with painting and insulating glass in two-chamber form (three sheets of glass) with painting cutting, finishing, painting, tempering and insulating.

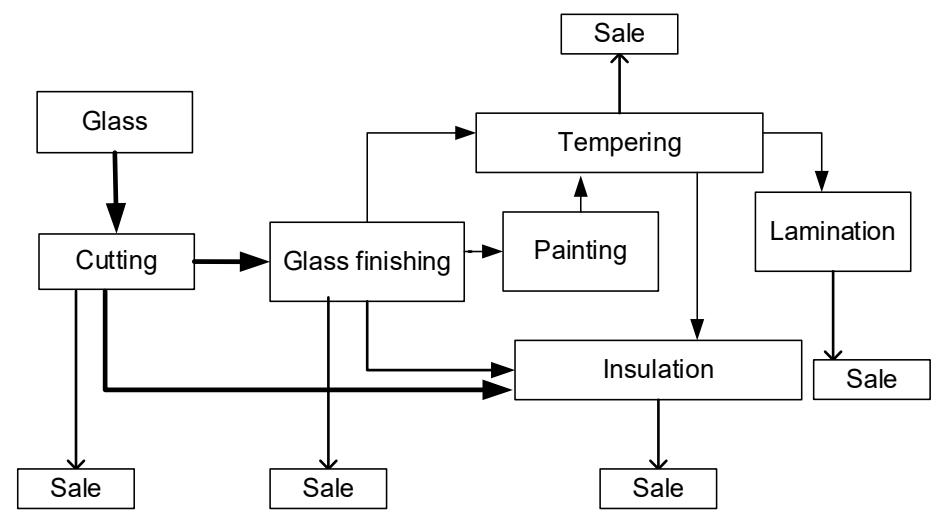

Fig. 2. Production process scheme.

The monthly production data for products and the use of processes are shown in Table 1 . The monthly consumption of elec- tricity per unit of production $\left(/ \mathrm{m}^{2}\right)$ for each process is shown in Table 2 .

Table 1. Monthly Production of Goods $\left(\mathrm{m}^{2}\right)$

\begin{tabular}{|l|c|c|c|c|c|c|c|}
\hline & $\mathrm{m}^{2}$ & Cutting 1 & Finishing 2 & Tempering 3 & Lamination 4 & Insulating 5 & Painting 6 \\
\hline Structural glazing & 500 & 500 & 500 & & & & \\
\hline $\begin{array}{l}\text { Insulating glass in single- } \\
\text { chamber form (two sheets } \\
\text { of glass) }\end{array}$ & 900 & 1,800 & 900 & & & & \\
\hline Tempered glass & 7,600 & 7,600 & 7,600 & 7,600 & & & \\
\hline Laminated glass & 200 & 400 & 400 & 400 & 200 & & \\
\hline $\begin{array}{l}\text { Insulating glass in two- } \\
\text { chamber form (three } \\
\text { sheets of glass) }\end{array}$ & 1,000 & 3,000 & 2,000 & 2,000 & & & \\
\hline $\begin{array}{l}\text { Insulating glass in single- } \\
\text { chamber form (two sheets } \\
\text { of glass) with painting }\end{array}$ & 50 & 100 & 50 & 50 & & & 50 \\
\hline $\begin{array}{l}\text { Insulating glass in two- } \\
\text { chamber form (three sheets of } \\
\text { glass) with painting }\end{array}$ & 150 & 450 & 300 & 150 & & & 50 \\
\hline
\end{tabular}


Table 2. Monthly Production Data for Goods and Electricity Consumption

\begin{tabular}{|l|c|c|c|}
\hline & Area of glass, $\mathrm{m}^{2}$ & Electricity consumption, $\mathrm{kWh}$ & Specific electricity consumption, $\mathrm{kWh} / \mathrm{m}^{2}$ \\
\hline Cutting & 13.85 & $4,666.60$ & 0.33 \\
\hline Finishing & 11.75 & $4,624.40$ & 0.39 \\
\hline Tempering & 10.20 & $6,4926.30$ & 6.36 \\
\hline Lamination & 200 & 893.01 & 4.46 \\
\hline Insulating & 2.10 & $5,579.25$ & 2.65 \\
\hline Painting & 200 & 919.81 & 4.60 \\
\hline
\end{tabular}

The percentage of the electricity consumption for each technological process is shown in Fig. 3. All the processes start with glass cutting. The tempering process takes the greatest amount of electricity and increases the value of the finished product.

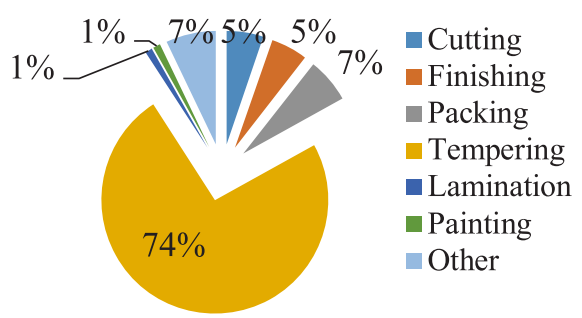

Fig. 3. The percentage share of the production process.

\section{B. The Strategy of Optimal Load Scheduling}

In this case study, the production plan is determined by the quantity of glass that has to be processed $\left(\mathrm{m}^{2}\right)$. The capacity for each process is given in Table 2, together with the electricity consumption and specific power consumption $\left(\mathrm{kWh} / \mathrm{m}^{2}\right)$. The sequence of the processes to produce each product is given in Fig. 2, but the time of production can be chosen, taking into account such factors as the electricity price and maximum allowable consumption. Products must be produced as a sequence of processes, but multiple products can be produced at the same time through simultaneous use of the processes: cutting, finishing, packaging, tempering, lamination, and painting.

Load scheduling (production by priority) may be solved by means of linear programming; in this paper, minimising annual cost $\left(C_{\text {base }}\right)$ for the energy consumption of the factory has been set as the optimisation objective of load scheduling.

Given that production must follow a strict order of process (e.g., cutting, glass finishing, tempering, lamination, insulating and painting), it is important to start with the first process (cutting), followed by any others to produce the finished product (see Table 1).

Allocation of the hourly power for five (out of the six) processes by priority can be achieved by using the following steps. Note that the maximum total energy consumption per hour is constrained. Consideration should also be given to the constraint on the capacity of the first process.

1. Determine the number of hours (NH1) that are required for the first volume process (glass cutting, Fig. 2) for an order. 
2. Adjust the timing of the first process so that the total energy consumption remains constant.

3. Determine the number of hours $\mathrm{NH} 2$ required for the second process (glass finishing, Fig. 2) for an order. This process should start as soon as possible and run from at least the second hour of the NH1 time period.
4. Determine the number of hours NH3, $\mathrm{NH} 4, \mathrm{NH} 5$ required for any further process steps (glass lamination, insulating and painting, Fig. 2) to complete production that can start at the same time.

The constraints of the task are:

The total hourly consumption of all the processes shall not exceed the maximum permissible consumption for the factory:

$\sum_{n=1}^{N} W_{\text {cons }, n, t} \leq W_{\text {max }}, \quad \forall n \in N, \forall t \in T_{\text {plan }}$

where

$W_{\max }$ - total maximum permitted hourly consumption of the factory, $\mathrm{kWh}$;

The hourly consumption of each process must not exceed its maximum permitted hourly consumption:

$W_{\text {cons }, n, t} \leq W_{\max n}, \quad \forall n \in N, \forall t \in T_{\text {plan }}$

where

$W_{\max n}$ - the maximum permitted consumption of the $n$-th process, $\mathrm{kWh}$.

\section{Input Data and Assumptions}

For the case study, we consider two cases for comparison:

1. The base case, when the factory does not have PV technology and has load scheduling in place.

2. The case when the factory has PV technology and optimal load scheduling is used.

The following conditions are taken into account in the simulation:

a. A fixed fee for connection is applied in accordance with the pricing policy [26]. b. The mandatory procurement component fee is applied in accordance with the pricing policy of 11 July 2018 [27].

c. The charges for system services or distribution and transmission services are applied in accordance with the existing pricing policy. The basic tariff is used [26].

d. The company operates one shift. The shift starts at 8:00 and ends at 17:00. Consequently, the optimisation period for load scheduling is 9 hours.

e. Data for electricity consumption of the factory from 2018 are used. 
f. The Nord Pool [28] day-ahead electricity price records from 2018 are used.

g. Energy production data by PV are taken from a specific facility in Latvia [20]. PV installed power is $33 \mathrm{~kW}$.

h. Data for electricity price, PV generation and factory consumption from 2018 are assumed to have remained constant for the analysis period.

i. PV generation is used to provide power supply of the glass tempering line, which works continuously.

j. The distribution fee for energy consumption is divided into three periods according to the S8 tariffs: day zone
(7:00 to $8: 00,10: 00$ to $17: 00$, and $20: 00$ to $23: 00)$, peak hour zone $(8: 00$ to $10: 00,17: 00$ to $20: 00)$ and night zone (23:00 to 7:00).

$\mathrm{k}$. Each process is assigned power consumption per square meter of production of glass $(w)$ as in Table 3.

1. The total maximum hourly permissible consumption $\left(W_{\max }\right)$ is $550 \mathrm{kWh} / \mathrm{h}$.

m. The maximum permissible consumption for each process is given in Table 4 .

n. The optimal load distribution is determined using linear programming.

o. Subsidies are not applied.

Table 3. Specific Consumption Process $\left(\mathrm{kWh} / \mathrm{m}^{2}\right)$

\begin{tabular}{|c|c|c|c|c|}
\hline Cutting & Finishing & Packaging & Painting & Lamination \\
\hline$w_{1}$ & $w_{2}$ & $w_{3}$ & $w_{4}$ & $w_{5}$ \\
\hline 0.34 & 0.4 & 2.65 & 4.40 & 4.65 \\
\hline
\end{tabular}

Table 4. Maximum Permitted Consumption (kWh/h)

\begin{tabular}{|c|c|c|c|c|}
\hline Cutting & Finishing & Packaging & Painting & Lamination \\
\hline$W_{\max 1}$ & $W_{\max 2}$ & $W_{\max 3}$ & $W_{\max 4}$ & $W_{\max 5}$ \\
\hline 35 & 35 & 50 & 15 & 15 \\
\hline
\end{tabular}

The NPV is calculated for four alternatives:

1. Alternative 1 - taking a loan and considering the total avoided costs from the PV installation and load scheduling $\left(C_{\left.A C_{\text {_total }}\right) \text { : }}\right.$

$$
N P V\left(T_{\text {plan }}\right)=-p_{\text {inv }}+\sum_{y=1}^{T_{\text {plan }}} \frac{C_{A C_{-} \text {total }, y}-\left(\frac{p_{\text {inv }}}{T_{\text {plan }}}+p_{\text {loan }, y} \cdot i\right)}{\left(1+i_{d}\right)^{y}}
$$

where

$C_{A C_{-} \text {total, } y}$ - total avoided cost (AC) of the consumer in year $y, €$; - remaining amount of the loan in year $y, € ; p_{\text {loan, } y}-$ the credit rate, $\%$.

2. Alternative 2 - taking a loan and considering the total avoided costs from the PV installation $\left(C_{A C_{P V}}\right)$ :

$N P V\left(T_{\text {plan }}\right)=-p_{\text {inv }}+\sum_{y=1}^{T_{\text {plan }}} \frac{C_{A C_{P V}, y}-\left(\frac{p_{\text {inv }}}{T_{\text {plan }}}+p_{\text {loan }, y} \cdot i\right)}{\left(1+i_{d}\right)^{y}}$ 
3. Alternative 3 - without taking a loan and considering the total avoided costs from the PV installation and load scheduling $\left(C_{A C_{\text {_total }}}\right)$. If the consumer does not take a loan, the second term in the numerator in (11), $\left(\frac{p_{\text {inv }}}{T_{\text {plan }}}+p_{\text {loan } y} \cdot i\right)$ is equal to zero.

4. Alternative 4 - without taking a loan and considering the total avoided costs from the PV installation $\left(C_{A C_{P V}}\right)$ without load scheduling. If the consumer does not take a loan, the second term in the numerator in (12), $\left(\frac{p_{\text {inv }}}{T_{\text {plan }}}+p_{\text {loan }, y} \cdot i\right)$ is equal to zero.

The economic and technical assumptions are summarised in Table 5

Table 5. Key Assumptions

\begin{tabular}{|c|c|}
\hline Name of Parameter; Measuring Unit & Value* \\
\hline Rated maximum allowable current of the factory, A & 909 \\
\hline Electricity distribution tariff & S-8 \\
\hline Mandatory procurement component, $€ / \mathrm{kWh}$ & 0.0178 \\
\hline \multicolumn{2}{|l|}{ Electricity distribution fee, $€ / \mathrm{kWh}$ : } \\
\hline - day zone & 0.039 \\
\hline - peak hour zone & 0.055 \\
\hline - night zone/weekend & 0.0306 \\
\hline Mandatory procurement component for the connection, $€ / \mathrm{A} /$ year & 8.71 \\
\hline Capacity-based connection fee to the distribution system operator, $€ / \mathrm{A} /$ year & 13.96 \\
\hline Loan interest rate [29], \% & 2.6 \\
\hline Discount rate, $\%$ & 2.0 \\
\hline Planning time, years & 25 \\
\hline Capacity of PV technology, kW & 33 \\
\hline Investment in PV technology, $€ / \mathrm{kW}$ & $1,242.0$ \\
\hline Efficiency of PV technology, \% & 18 \\
\hline
\end{tabular}

*Data for 2019

For this study, we assume that the cost of purchasing and installing the PV system for a $33 \mathrm{~kW}$ PV technology is approximately $41,000 €[30]$. However, it is expected that in the near future the prices

\section{Results}

The results of energy produced and the $\mathrm{AC}\left(C_{A C_{P V}, y}\right)$ from the $\mathrm{PV}$ installation in of PV will decrease, which serves as evidence of the real prices for powerful solar stations. For example, in Pärnu, Estonia, the price per $\mathrm{kW}$ of a new $3.96 \mathrm{MW}$ solar power plant is $883.83 €$ [31].

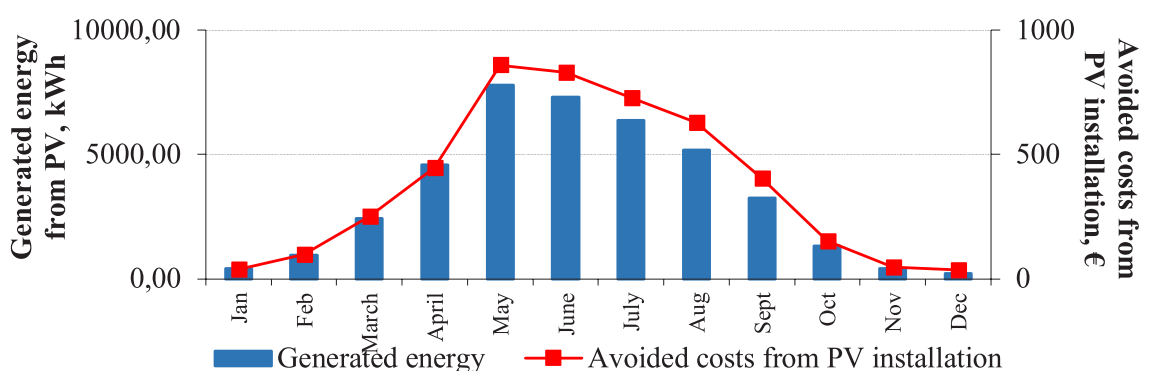

Fig. 4. Energy produced and the AC from PV technology by month. 
Figure 4 shows how generation varies by season, with the spring/summer period providing the greatest output.

The annual energy produced by a $33 \mathrm{~kW}$ PV technology is $40,015 \mathrm{kWh}$. We assume all the generated electricity is consumed by the factory in place of electricity taken from the grid. Figure 5 shows an example of the consumption of one process and the energy generated by the PV in May.

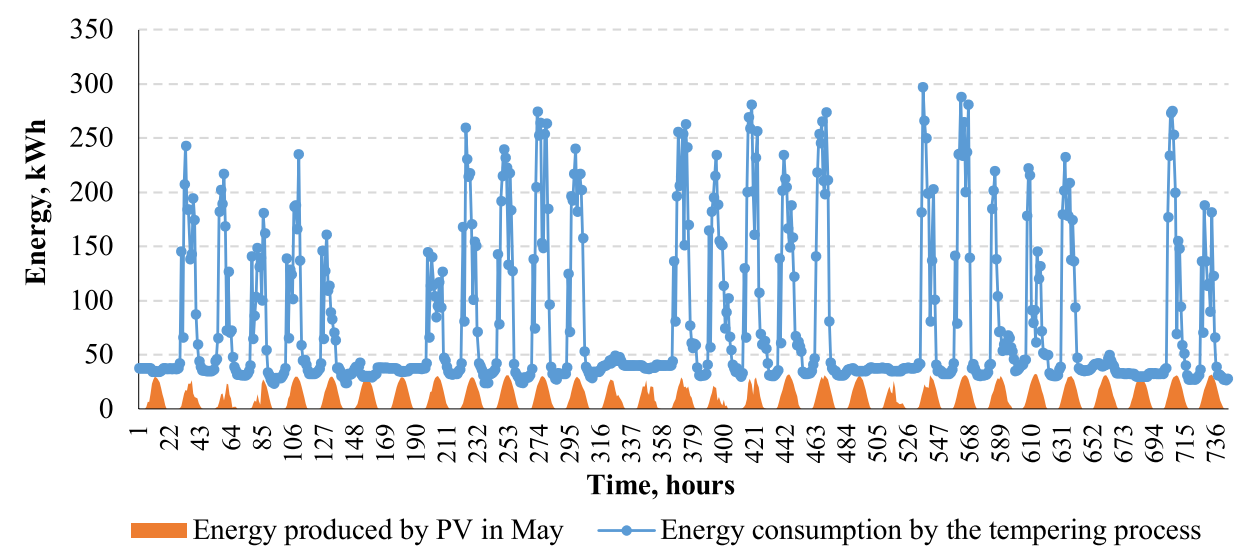

Fig. 5. Energy produced by the PV and the energy consumption by the tempering process in May.

Given all generated electricity is consumed, a net metering system (NMS) [31] is not be required. Information on an NMS can be found in our previous work [32]. Residential PV generation differs in this respect, as it will export to and consume from the grid. Information about the net metering system can be found in our previous work [33].

Figure 6 shows an example of optimal load distribution, with the load distribution before and after optimisation for the glass cutting process.

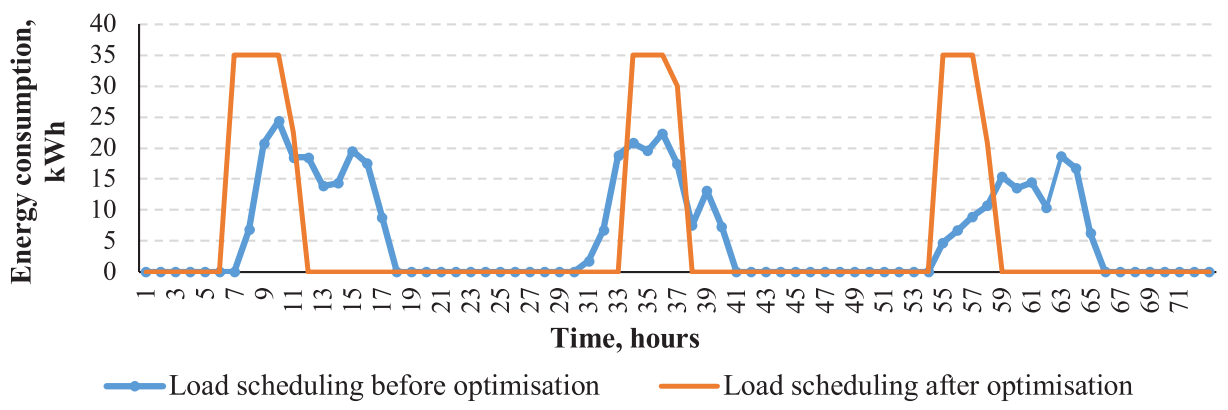

Fig. 6. Fragment of load scheduling before and after optimisation for the glass cutting process (01/01/2018-03/01/2018).

Figure shows that the entire load should be concentrated in the hours when the price is lowest, thereby reducing the energy cost.
Figure 7 shows the change in the NPV over time for the four alternatives. 


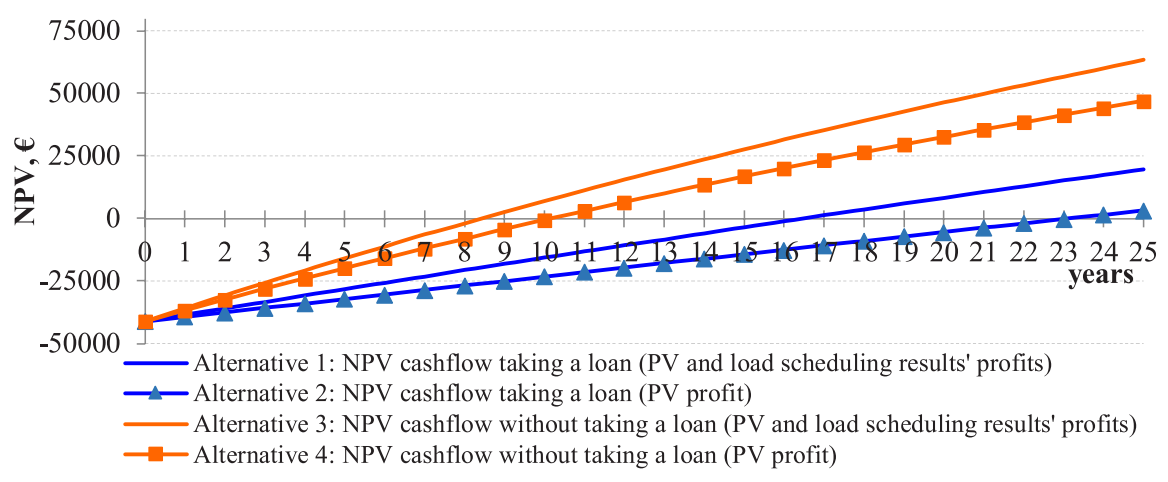

Fig. 7. NPV cash flow.

The annual income to the factory from the utilisation of $\mathrm{PV}$ is 4,509€ (Fig. 4), assuming the utilisation of energy is adapted to take full advantage of its generation. The estimated NPV for PV is shown to have a positive tendency. Figure 7 demonstrates that Alternative 3 is the most profitable (no loan with load scheduling); PP is eight years and the total NPV is $63,430 €$. Alternative 2 is the least profitable (loan and no load scheduling); PP is twenty-three years and the NPV is 3,346€. For Alternative 1, the PP is sixteen years and for Alternative 4 the PP is ten years.

We use Alternative 2 and Alternative 4 and data from [32] to compare the PP between industrial and residential use of PV technology.

In accordance with the study "Evaluation of the Net Metering System and Suggestions for System Improvements" [33], we would like to emphasise the following input data and conclusions:

- NMS was applied to residential PP. Energy surplus is exported.

- Average Residential PV capacity is assumed to be $5.5 \mathrm{~kW}$.

- Two scenarios of NMS were considered:

- Case A: it is assumed that there is complete $(100 \%)$ direct consumption (DirC) of all generated electricity. In the case of a no-loan situation, the PP is 11 years. In the case of a loan, the PP is 25 years.

- Case B: export and consumption vary but there is an overall balance in annual electricity use. In the case of a no-loan situation, the PP is 26 years. With a loan, the PP is more than 28 years.

The comparison between the PP of industrial and residential is summarised in Table 6 .

Table 6. Payback Period Comparison

\begin{tabular}{|l|c|c|}
\hline \multirow{2}{*}{ Initial data and circumstances } & \multicolumn{2}{|c|}{ Type of consumer } \\
\cline { 2 - 3 } & Industrial & Household \\
\hline Capacity of PV technology, $\mathrm{kW}$ & 33 & 5.5 \\
\hline Investments in PV technology, $€$ & 40990 & 600 \\
\hline Payback period, years: & & \\
\hline Without loan & 8 (Alternative 3) & 26 (if DirC is 20\%) \\
\hline With loan & 10 (Alternative 4) & (if DirC is $100 \%$ ) \\
\hline
\end{tabular}


Table 6 indicates that PV is more profitable for industrial installation (large enterprises) than for residential (small users). This arises from the lower cost of installation for a large power PV than low-power $\mathrm{PV}$ and the difference in tariff costs. In addition, direct consumption has a significant impact on the economic benefits of using the PV technology, i.e., the higher the direct consumption, the lower the total cost of electricity. In the case of a factory, the direct consumption is $100 \%$, whereas typical EU residential direct consumption is between 20 and $30 \%$ [33].

\section{CONCLUSIONS}

The increase in energy consumption and climate change contribute to a wider use of renewable energy resources. The paper has investigated the economic incentives for use of PV technologies.

Installation and use of PV technology are most beneficial to users with high direct consumption. It is also most financially attractive to users who are able to invest in the PV rather than as a loan. The greatest benefit from PV comes by combining the use of PV and applying optimal load scheduling.

For industrial enterprises, the average $\mathrm{PP}$ of the PV technology is 23 years if a loan is taken, compared to 10 years if no loan is taken. For residential users with NMS, the PP is 26 years. Such a PP is too long to incentivise the use of RES technologies.

In all analyses, the prevailing tariffs will affect the PP.

\section{ACKNOWLEDGEMENTS}

The research has been funded by the Ministry of Economics of the Republic of Latvia, project "Innovative Smart Grid Technologies and their Optimization (INGRIDO)", project No. VPP-EM-INFRA-2018/1-0006 and project "Future-proof Development of the Latvian Power System in an Integrated Europe (FutureProof)", project No. VPPEM-INFRA-2018/1-0005.

This paper has been supported by the
European Regional Development Fund within the activity 1.1.1.2 "Post-doctoral Research Aid" of the Specific Aid Objective 1.1.1 "To increase the research and innovative capacity of scientific institutions of Latvia and the ability to attract external financing, investing in human resources and infrastructure" of the Operational Programme "Growth and Employment" (No.1.1.1.2/VIAA/2/18/317).

\section{REFERENCES}

1. IEA. (2018). Renewables 2018. Analysis and forecasts to 2023. Available at https:// www.iea.org/reports/renewables-2018

2. Power Technology (2020). The World's Most Used Renewable Power Sources. Available at https://www.power-technology. com/features/featurethe-worlds-most-used- renewable-power-sources-4160168

3. Feldman, D., Barbose, G., Margolis, R., Wiser, R., Goodrich, A., \& Darghouth, N. (2012). Photovoltaic (PV) Pricing Trends: Historical, Recent, and Near-Term Projections. Available at https://www.nrel. gov/docs/fy13osti/56776.pdf 
4. Mutule, A., Zikmanis, I., \& Dumitrescu, A.-M. (2020). Electric Consumption Assessment Using Smart Meter Data and KPI Methodology. Latvian Journal of Physics and Technical Sciences, 57 (3), 3-19. doi: 10.2478/lpts-2020-0011.

5. Sauhats, A., Zemīte, L., Petričenko, L., Moškins, I., Jasevičs, A. (2018). Estimating the Economic Impacts of Net Metering Schemes for Residential PV Systems with Profiling of Power Demand, Generation, and Market Prices. Energies, 11 (11), 1-19. doi:10.3390/en11113222.

6. IRENA. (2015). Renewable Energy Options for the Industry Sector: Global and Regional Potential until 2030. Available at https:// www.irena.org/-/media/Files/IRENA/ Agency/Publication/2014/Aug/IRENA RE_Potential_for_Industry_BP_2015.pdf

7. Mekhilef, S., Rahman, S. \& Safari, A. (2011). A Review on Solar Energy Use in Industries. Renewable and Sustainable Energy Reviews, 15 (4), 1777-1790.

8. Ma, J., Elkasrawy, A., Yu, D., \& Venkatesh, B. (2015). Demand Response Literature Review. Ryerson University. Centre for Urban Energy. Available at https:// www.ryerson.ca/content/dam/cue/pdfs/ FinalDemandResponse.pdf

9. Goldman, C., Reid, M., Levy, R., \& Silverstein, A. (2010). Coordination of Energy Efficiency and Demand Response. US: Lawrence Berkeley National Lab. doi:10.2172/981732.

10. SEDC. (2017). Explicit Demand Response in Europe - Mapping the Markets 2017. Belgium, Brussels. Available at https:// smarten.eu/wp-content/uploads/2017/04/ SEDC-Explicit-Demand-Response-inEurope-Mapping-the-Markets-2017.pdf

11. European Commission. (2012). Annual Report on Small and Medium-Sized Enterprises in EU. Belgium, Brussels.

12. European Parliament. (2012). Directive 2012/27/EU on Energy Efficiency, Amending Directives 2009/125/EC and 2010/30/EU and Repealing Directives 2004/8/EC and 2006/32/EC. Official Journal of the European Union, L315/1.
13. Arnold, K., \& Janssen, T. (2016). Demand side management in industry - necessary for a sustainable energy system or a backward step in terms of improving efficiency? In ECEEE Industrial Summer Study, (pp. 339 350), 12-14 September 2016, Kalkscheune, Berlin, Germany.

14. Castro, P., Harjunkoski, I., \& Grossmann, I. (2011). Optimal Scheduling of Continuous Plants with Energy Constraints. Computers \& Chemical Engineering, 35, 372-387. doi:10.1016/j.compchemeng.2010.05.008

15. Haït, A., \& Artigues, C. (2011). On Electric Load Tracking Scheduling for a Steel Plant. Computers \& Chemical Engineering, 35, 3044-3047. doi: 10.1016/j.compchemeng. 2011.03.006

16. Leo, E., \& Engell, S. (2018). Integrated DayAhead Energy Procurement and Production Scheduling. Automatisierungstechnik, 66, 950-963. doi:10.1515/auto-2018-0016.

17. Solargis. (n.d.). SolarGIS Map. Available at https://solargis.com/maps-and-gis-data/ download/

18. Solenergo. (n.d.). Solar Batteries. Available at http://solenergo.lv/saules-baterijas (in Latvian).

19. Latvian Environment, Geology and Meteorology Centre. (n.d.). Meteorological Data Availability. Available at https://www. meteo.lv/meteorologija-datu-pieejamiba/?i $\mathrm{By}=$ parameter\&nid $=462 \&$ pMonitoringTyp $\mathrm{e}=$ METEOROLOGY\&iParameter $=4220 \& \mathrm{i}$ Station $=30046$

20. SolarEdge. (n.d.). SolarEdge Monitoring Platform. Available at https://monitoringpublic. solaredge.com/solaredge-web/p/home/ public?locale=en_US

21. Chris, G. (2009). Direct and Indirect Uncertainties in the Prediction of Tilted Irradiance for Solar Engineering Applications. Solar Energy, 83 (3), 432444. doi: 10.1016/j.solener.2008.11.004.

22. Short, W., Packey, D.J. \& Holt, T. (1995). A Manual for the Economic Evaluation of Energy Efficiency and Renewable Energy Technologies. Colorado. Available at http:// www.nrel.gov/docs/legosti/old/5173.pdf 
23. Petričenko, L.,, Broka, Z., Sauhats, A., \& Bezrukovs, D. (2018). CostBenefit Analysis of Li-Ion Batteries in a Distribution Network. In 2018 15th International Conference on the European Energy Market (EEM 2018), (pp. 1-5), 2729 June 2018, Lodz, Poland. doi:10.1109/ EEM.2018.8469782

24. Kessler, W. (2017). Comparing Energy Payback and Simple Payback Period for Solar Photovoltaic Systems. E3S Web of Conferences, 22 (12): 00080. doi:10.1051/ e3sconf $/ 20172200080$.

25. Fahnehjelm, C., \& Amting, V. (2016). Evaluation of Cost Competitiveness and Payback Period of Grid-Connected Photovoltaic Systems in Sri Lanka. The Royal Institute of Technology. Available at http://www.diva-portal.org/smash/get/ diva2:1069584/FULLTEXT01.pdf

26. AS Sadales tīkls. (2020). Electricity Distribution Differential Tariffs. Available at https://www.sadalestikls.lv/ uploads/2020/01/ST_tarifi_2020.pdf

27. SPRK (n.d.). Mandatory Procurement Component. Available at https://www.sprk. gov.lv/en/node/128

28. Nord Pool. (n.d.). Nord Pool Electrical Energy Price Statistics. Available at http:// www.nordpoolspot.com/Market-data 1/ Elspot/Area-Prices/
29. Bank of Latvia. (n.d.). Bank Interest Rates. Available at https://www.bank.lv/statistika/ dati-statistika/procentu-likmju-statistikasraditaji/galvenas-procentu-likmes [in Latvian]

30. Ministry of Economics. (n.d.). Field Policy. Available at https://www. em.gov.lv/files/nozares_politika/ELIS NETO_10.08.2018_nodevums.pdf (in Latvian).

31. GAAS. (n.d.). Estonia's Largest Solar Plant Started operating in Parnu. Available at https://www.gaas.ee/en/estonia-s-largestsolar-power-plant-started-operating-inparnu/ (in Estonian).

32. Petričenko, L., Zemīte, L., Sauhats, A., Klementavicius, A., \& Grickevics, K. A Comparative analysis of supporting policies for solar Pv systems in the Baltic Countries. In 2019 IEEE International Conference on Environment and Electrical Engineering and 2019 IEEE Industrial and Commercial Power Systems Europe, (pp. 1-6), 11-14 June 2019, Genoa, Italy. doi:10.1109/ EEEIC.2019.8783838.

33. Zemīte, L., Sauhats, A., Petričenko, L., Kozadajevs, J., \& Bezrukovs, D. (2018). Elektroenergijas NETO sistēmas izvērtējums un priekšlikumi sistēmas uzlabojumiem. RTU. Available at https:// www.em.gov.lv/lv/media/649/download (in Latvian). 